\title{
Feedbacks from human health to household reliance on natural resources during the COVID-19 pandemic
}

Originating from the wildlife trade and emerging as a global pandemic, COVID-19 has shown how exploitation of natural resources can negatively affect human health. More broadly, there is growing recognition of the diverse ways that environmental degradation (eg, deforestation and climate change) negatively affects human health through myriad pathways (eg, increased risk of disease spillover from wildlife to humans). Less attention has been given to how human health then feeds back to affect the environment and exacerbate harm to people. By affecting livelihoods and natural resource use, health shocks can create a feedback loop, compounding negative consequences for both human and environmental health.

In the wake of COVID-19, households around the world are coping with poor health and a milieu of measures for disease control. Understanding changes in strategies for household livelihoods is fundamental to mitigating adverse consequences on local environments and key to the long-term welfare of vulnerable households. We use the sustainable livelihoods framework, a tool that is widely used in development and antipoverty literature, ${ }^{1}$ to examine feedbacks from human health to the environment.

The sustainable livelihoods approach emphasises how households balance a portfolio of capitals to cope with adversity, including health shocks (appendix $\mathrm{p} 1$ ). Human capital (eg, health, knowledge, and work capacity) is acutely affected when household members become sick or die. Wage and job loss driven by a pandemic transforms household financial capital (eg, savings, credit, and wages), whereas lockdowns and measures for disease control restrict access to social capital (eg, relationships and networks) and physical capital (eg, infrastructure and technology). As other types of capital are drawn down or become less accessible, people in vulnerable positions might lean particularly hard on natural capital (eg, land, water, and wildlife). ${ }^{2,3}$ Institutions and governance regimes integrally shape the ways that households balance their capital portfolios, and we focus particularly on communities with minimal institutional safety nets.

The loss of human capital to morbidity and mortality necessitates that households compensate for lost wages and food sources and can lead to a loss of labour, ecological knowledge, or leadership in environmental management. ${ }^{4}$ HIV/AIDS mortality, for example, has contributed to long-term declines in agricultural production across southern Africa. ${ }^{5}$ When household members with AIDS die, surviving family members are more likely to rely on hunting and foraging. ${ }^{6}$ In Kenyan fishing communities, people are more likely to use illegal and destructive fishing practices when they are sick.? Similarly, the acute outbreak of Ebola virus in west Africa in 2014-16 led to increased consumption of fish stocks that were already overharvested. ${ }^{8}$ Crucially, when human health shocks also precipitate environmental degradation, such degradation further jeopardises the long-term viability of livelihoods that are dependent on natural resources. With over 27 million cases and nearly 900000 deaths by early September, 2020, the magnitude of COVID-19 on human capital loss promises to be tremendous and could hasten environmental degradation that compounds the growing human toll.

Responses to health shocks also reverberate across other types of household capitals. Financial capital declines as households earn less income, draw down from savings, and sell assets. To pay medical bills, households with low income might rely on lenders providing only predatory rates ${ }^{9}$ and the need to repay loans might drive overharvesting in fishing communities. ${ }^{10}$ During the COVID-19 pandemic, increased poaching for food has been observed in Indonesia, with snares further threatening vulnerable wildlife. ${ }^{11}$ Decreased urban employment has also led to declining international and domestic remittances, promising to escalate pressure on rural areas and nearby natural resources.

Stay-at-home measures also constrain access to social and physical capital. Distancing measures have separated households from the safety nets provided by social networks, which confer emotional, informational, and instrumental support, thereby buffering reliance on natural capital. Breakdowns in transportation and supply chains during the current pandemic have reduced people's access to the physical capital that moves goods for sale and consumption. In Kenya, for example, 
decreased access to cooking gas has driven up charcoal demand and pressure on forests. ${ }^{11}$

During the COVID-19 pandemic, reliance on natural capital is escalating in many communities and is symptomatic of struggling households with decreased access to other forms of capital. When the health and human capital of people who are most reliant on natural resources are harmed, the detrimental consequences for livelihoods can be compounded by environmental degradation. In the aftermath of this pandemic, we should invest in robust social and institutional structures that strengthen households' portfolios of diverse capitals and improve community resilience to all types of shocks. Such investments will help to forestall the feedback loops that erode all types of capital and lead to negative outcomes for health and the environment. If we do not rise to this challenge, natural resources will erode further and downstream effects on health and livelihoods can be expected.

We declare no competing interests.

Copyright $\odot 2020$ The Author(s). Published by Elsevier Ltd. This is an Open Access article under the CC BY-NC-ND 4.0 license.

*Kathryn J Fiorella, Jeanne Coffin-Schmitt, Kaitlyn M Gaynor, Gillian H Gregory, Ranaivo Rasolofoson, Katherine L Seto kfiorella@cornell.edu
Department of Population Medicine and Diagnostic Sciences (KJF, RR) and Department of Natural Resources (JC-S), Cornell University, Ithaca, NY 14853, USA; National Center for Ecological Analysis and Synthesis, University of California, Santa Barbara, CA, USA (KMG); School of Geography, University of Melbourne, Carlton, VIC, Australia (GHG); and Environmental Studies Department, University of California, Santa Cruz, CA, USA (KLS)

1 Chambers R, Conway G. Sustainable rural livelihoods: practical concepts for the 21st century. Brighton: Institute of Development Studies, 1992.

2 Brashares JS, Abrahms B, Fiorella KJ, et al. Wildlife decline and social conflict. Science 2014; 345: 376-78.

3 de Sherbinin A, VanWey LK, McSweeney K, et al. Rural household demographics, livelihoods and the environment. Global Environ Change 2008; 18: 38-53.

4 Talman A, Bolton S, Walson JL. Interactions between HIV/AIDS and the environment: toward a syndemic framework. Am J Public Health 2013; 103: 253-61.

5 Mason NM, Jayne TS, Chapoto A, Myers RJ. A test of the new variant famine hypothesis: panel survey evidence from Zambia. World Dev 2010; 38: 356-68.

6 Hunter LM, Twine W, Patterson L. "Locusts are now our beef": adult mortality and household dietary use of local environmental resources in rural South Africa. Scand J Public Health 2007; 35: 165-74.

7 Fiorella KJ, Milner EM, Salmen CR, et al. Human health alters the sustainability of fishing practices in east Africa. Proc Natl Acad Sci USA 2017; 114: 4171-76.

8 Seto K, Belhabib D, Mamie J, et al. War, fish, and foreign fleets: the marine fisheries catches of Sierra Leone 1950-2015. Mar Policy 2017; 83: 153-63.

9 Kruk ME, Goldmann E, Galea S. Borrowing and selling to pay for health care in low- and middle-income countries. Health Aff (Millwood) 2009; 28: 1056-66.

10 Ruddle K. "Informal" credit systems in fishing communities: issues and examples from Vietnam. Hum Organ 2011; 70: 224-32.

11 Conservation International. Conservation International reports increase in poaching and tropical deforestation due to COVID-19 restrictions. April 21, 2020. https://www.conservation.org/press-releases/2020/04/21/ conservation-international-reports-increase-in-poaching-and-tropicaldeforestation-due-to-covid-19-restrictions (accessed May 5, 2020). 


\section{University Library}

\section{- M M N E R VA A gateway to Melbourne's research publications}

Minerva Access is the Institutional Repository of The University of Melbourne

Author/s:

Fiorella, KJ;Coffin-Schmitt, J;Gaynor, KM;Gregory, GH;Rasolofoson, R;Seto, KL

Title:

Feedbacks from human health to household reliance on natural resources during the COVID-19 pandemic

Date:

2020-10-01

Citation:

Fiorella, K. J., Coffin-Schmitt, J., Gaynor, K. M., Gregory, G. H., Rasolofoson, R. \& Seto, K. L. (2020). Feedbacks from human health to household reliance on natural resources during the COVID-19 pandemic. LANCET PLANETARY HEALTH, 4 (10), pp.E441-E442. https:// doi.org/10.1016/S2542-5196(20)30199-6.

Persistent Link:

http://hdl.handle.net/11343/258718

License:

CC BY-NC-ND 